Janneke C. Alers · Pieter-Jaap Krijtenburg

Kees J. Vissers · Sheila K. Krishnadath

Fré T. Bosman · Herman van Dekken

\title{
Interphase in situ hybridization to disaggregated and intact tissue specimens of prostatic adenocarcinomas
}

Accepted: 1 June 1995

\begin{abstract}
A comparative study was performed of interphase in situ hybridization (ISH) to deparaffinized 4- $\mu \mathrm{m}$ tissue sections and nuclear suspensions from eight prostatic adenocarcinomas, as well as one normal prostatic control. Whole nuclear suspensions were derived from the same tumor areas to evaluate differences of ISH to truncated versus whole nuclei. DNA probes specific for the centromeres of chromosome $1,7,8,10$, and $Y$ were used for detection of numerical chromosomal changes and aneuploidy. In six adenocarcinomas chromosome aberrations $(+7,+8,-8,-10,-\mathrm{Y})$ were seen. However, ISH to sections revealed focal aberrations $(-10,-\mathrm{Y})$ in four cases that could not be distinguished in the suspensions. Chromosomal alterations occurring in larger tumor areas were also detected in the nuclear suspensions. Chromosome copy number changes, especially gains, were better discriminated in the nuclear suspensions. The rate of ISH aneuploidy seen in nuclear suspensions corresponded with that observed in the tissue sections $(P<0.01)$. Ploidy patterns as assessed by ISH to sections and nuclear suspensions were in concordance with DNA flow cytometry (both $P<0.001$ ). We conclude that both section and suspension ISH were able to accurately detect aneuploidy and numerical chromosomal aberrations occurring in larger histological areas. However, section ISH was also capable of revealing (small) focal cytogenetic abnormalities, due to a precise analysis of only target cells. Focal abnormalities were not detected by suspension ISH, probably due to an admixture of non-aberrant tumor cells and stromal elements.
\end{abstract}

\section{Introduction}

Interphase cytogenetic analysis by in situ hybridization (ISH) is increasingly being used to detect specific karyo-

J.C. Alers ( $)$ P.J. Krijtenburg · K.J. Vissers · S.K. Krishnadath

F.T. Bosman - H. van Dekken

Department of Pathology, Erasmus University Rotterdam,

PO Box 1738, 3000 DR Rotterdam, The Netherlands

Tel. +31-10-4087893; Fax +31-10-4366660 typic aberrations in human malignancies (Cremer et al. 1988; Hopman et al. 1989; Anastasi et al. 1990; van Dekken et al. 1990). Analysis of chromosome copy number is possible using probes that recognize chromosomespecific repeat sequences, such as (peri)-centromeric alpha satellite DNA. Results from interphase ISH studies on chromosome number are comparable to those obtained by classical karyotyping, and yield extra information in most cases (Poddighe et al. 1991; Micale et al. 1993). Also, ploidy of tumors can be established by interphase ISH, rendering data highly comparable with those measured by DNA flow cytometry (FCM; van Dekken et al. 1993; Persons et al. 1994). Most investigators have used tumor cells or nuclei disaggregated from fresh tumors or tissue blocks. However, the inevitable loss of tissue architecture prevents the analysis of relationships between chromosome changes and histopathological characteristics. Further, no discrimination between tumor and non-tumor cells can be made. To circumvent these problems, investigators have adapted ISH to routine paraffin sections (Hopman et al. 1991; van Dekken et al. 1992; Kim et al. 1993; Persons et al. 1993; Krishnadath et al. 1994; Zitzelsberger et al. 1994). A disadvantage of this technique is, however, that sectioning of the tissue blocks leaves the nuclei truncated. The latter phenomenon makes it more difficult to establish the precise chromosome copy number per nucleus.

The goal of the present study was to define the correlation of ISH spot numbers of truncated nuclei $(4-\mu \mathrm{m}$ sections) versus whole nuclei (suspensions), isolated from the same tissue area. Nine prostate specimens (eight adenocarcinomas, one normal) were chosen from an ongoing ISH study in which the section method was used (Alers et al. 1995a). A protocol for isolation of nuclei from deparaffinized tissue (Wang et al. 1993) was further optimized for ISH. We have used non-fluorescent (peroxidase/diaminobenzidine) visualization of the DNA probes, thus providing an optimal histological examination of target cells. Further, this approach is not biased by autofluorescence and fixation artifacts. The accuracy 


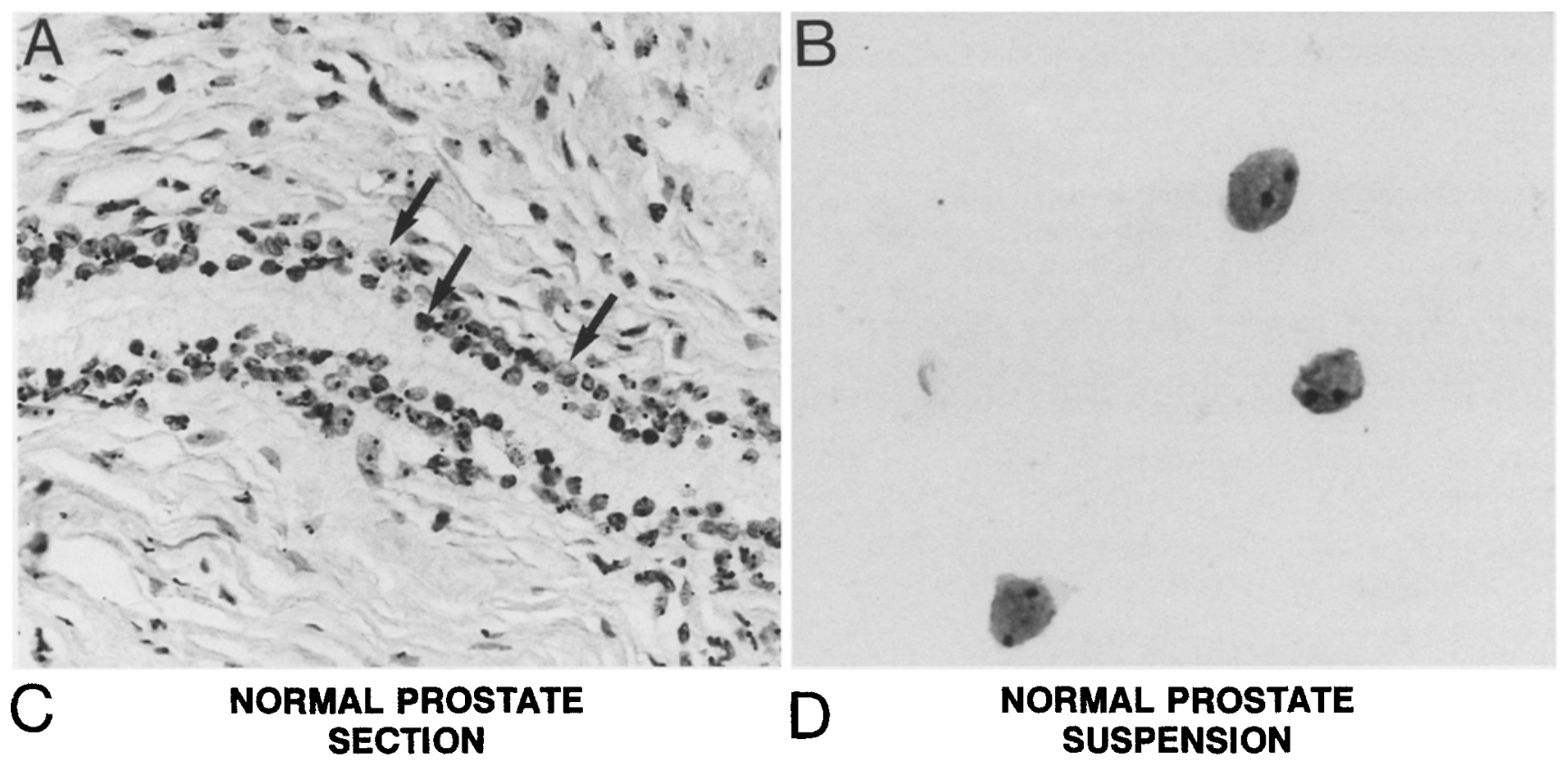

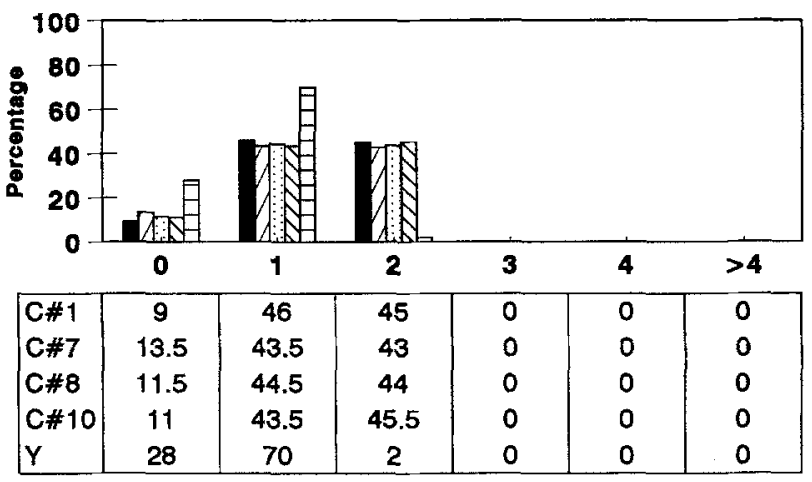

Number of ISH spots/ Nucleus

口

Fig. 1A In situ hybridization (ISH) with the chromosome-specific DNA probe set to a tissue section of a normal prostatic gland. Nuclei containing no, one or two spots are seen for chromosome 1 (arrows from right to left). The ISH-related spots were visualized with immunoperoxidase/diaminobenzidine (black); hematoxylin was used as a counterstain (gray). B ISH with the chromosome 1specific probe to the corresponding nuclear suspension. Nuclei displaying two spots are seen. Magnification: A $361 \times$, B $880 \times$. C Bar histogram showing the ISH spot distributions for the whole

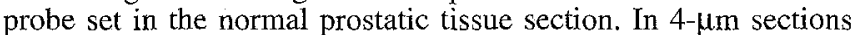
about half of the nuclei show no or one spot for the autosomes. D Bar histogram demonstrating the ISH spot distributions in nuclear suspensions. In suspensions, over $90 \%$ of the cells show the expected two spots per nucleus for the autosomes. Note the haploid distribution of chromosome $\mathrm{Y}$ in $\mathrm{C}$ and $\mathrm{D}$

of detecting numerical chromosome changes was then compared between section ISH and suspension ISH. In addition, we evaluated the ploidy status of the specimens as assessed by ISH to both sections and suspensions with DNA ploidy as measured by FCM.

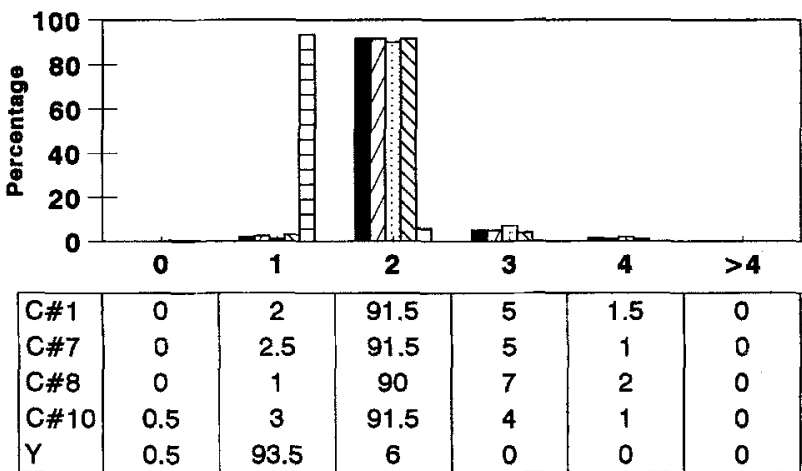

Number of ISH spots/ Nucleus

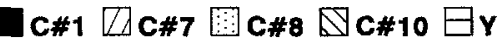

\section{Materials and methods}

Preparation of tissue sections

Routinely processed, formalin-fixed, paraffin-embedded materials from radical prostatectomies of eight patients with primary prostatic adenocarcinoma were used in this study. Patients had not received endocrine treatment prior to surgery. One autopsy specimen from a patient, who died from an unrelated disease, was used as a normal control. Tumors were graded according to the Gleason system, which recognizes nine growth patterns, which are arranged in five grades, with increasing loss of histological differentiation (Gleason 1992). ,Low-grade" tumors have a total Gleason score of $\leq 6$, ,highgrade" tumors a score of $\geq 7$. In situ hybridization (ISH) was performed on consecutive $4-\mu \mathrm{m}$ tissue sections. This section size was chosen after evaluating the degree of nuclear overlap (countability) and section thickness. Sections were mounted with distilled water on microscope glass slides coated with aminoalkylsilane (Sigma, St. Louis, Mo., USA) and baked overnight at $60^{\circ} \mathrm{C}$ for better adherence.

Preparation of nuclear suspensions

The Gleason areas, analyzed on the tissue section, were selectively cut out from the paraffin blocks with a fine scalpel blade. The low- 
Table 1 In situ hybridization (ISH) to tissue sections, to nuclear suspensions, and DNA flow cytometry $(F C M)$ of eight prostatic adenocarcinomas

\begin{tabular}{|c|c|c|c|c|c|c|}
\hline \multirow[t]{2}{*}{ Case } & \multirow{2}{*}{$\begin{array}{l}\text { Grade } \\
\text { area }^{\mathrm{a}}\end{array}$} & \multirow[t]{2}{*}{$\mathrm{FCM}^{\mathrm{b}}$} & \multicolumn{2}{|c|}{ Aneuploidy ${ }^{\mathrm{c}}$} & \multicolumn{2}{|l|}{ Aberrations ${ }^{d}$} \\
\hline & & & Section & Suspension & Section & Suspension \\
\hline 1 & Low/G2+G3 & $\mathrm{T}(18)$ & $20^{c}$ & 16 & - & - \\
\hline 2 & Low/G2+G3 & $\mathrm{D}(8)$ & $12.5^{\mathrm{c}}$ & 13 & $-Y$ & $-\mathrm{Y}$ \\
\hline 3 & Low/G3 & $\mathrm{D}(10)$ & 4.5 & 5 & -10 & - \\
\hline 4 & $\mathrm{High} / \mathrm{G} 3+\mathrm{G} 5$ & D (4) & 2 & 17.5 & $-\mathrm{Y}$ & +7 \\
\hline 5 & $\mathrm{High} / \mathrm{G} 3+\mathrm{G} 5$ & $A(23)$ & $18.5^{\mathrm{c}}$ & 39 & $-Y$ & $-Y$ \\
\hline 6 & $\mathrm{High} / \mathrm{G} 5^{\mathrm{f}}$ & $T(44)$ & 41 & 67 & $+7,+8,-10$ & $+7,+8$ \\
\hline 7 & High/G5 & $\mathrm{T}(22)$ & 6.5 & 28.5 & $-8,-Y$ & -8 \\
\hline 8 & $\mathrm{High} / \mathrm{G} 5$ & $\mathrm{~T}(40)$ & 42.5 & 52 & - & - \\
\hline
\end{tabular}

a Gleason grade/area(s) investigated

${ }^{b} D$ (iploid): $\leq 10 \%$ of cells in non-2C peak; $T$ (etraploid): $>10 \%$ of cells in non-2C peak; $A$ (neuploid): extra non-2C peak. The percentage of non-2C peak cells is given in parenthesis

c Percentage of cells with more than two ISH spots for chromosome 1 per nucleus. In normal control cells, fewer than $2.5 \%$ of cells contain more than two spots

d Chromosomal ISH aberration: $P<0.01$ in Kolmogorov-Smirnov test

e Mean percentage of aneuploid cells of two adjacent Gleason areas

${ }^{f}$ In this G4+G5 grade tumor only the grade 5 area was evaluated for both section and suspension. The grade 4 area was on a separate tissue block er boundaries were then examined for the presence of tumor and the histological grade on hematoxylin and eosin-stained sections. Correspondence between upper and lower boundaries was seen in all tumor samples. Nuclear suspensions were obtained according to an improved Hedley protocol (Hedley et al. 1983; Heiden et al. 1991; Wang et al. 1993). Briefly, after deparaffination and rehydration, samples were digested in $1.5 \mathrm{ml}$ of Carlsberg solution $[0.1 \%$ Sigma protease XXIV (subtilisin), 0.1 $M$ TRIS, $0.07 M$ $\mathrm{NaCl}, \mathrm{pH} 7.2]$ for $50 \mathrm{~min}$ at $37^{\circ} \mathrm{C}$ in a shaking water bath, with vigorous vortexing every $5 \mathrm{~min}$. Subtilisin resulted in higher yields and less aggregation of the nuclei than digestion in $0.5 \%$ pepsin. Cell suspensions were centrifuged briefly and rinsed in PBS before filtering through a nylon mesh (pore size $40 \mu \mathrm{m}$ ) to remove aggregates of cells and debris. Suspensions were resuspended in PBS and sheared several times by vigorously passing the cells through a small syringe. Samples were then stored in ethanol:acetic acid $(3: 1)$ at $-20^{\circ} \mathrm{C}$.

Probe set and probe labelling

A probe set specific for chromosomes $1,7,8,10$, and $\mathrm{Y}$ was selected. Selection criteria were based on literature data considering numerical (and structural) aberrations in prostate and other solid tumors (Arps et al. 1993; Brothman et al. 1990; Lundgren et al. 1992). The sources of the (peri)centromeric probes were as follows: chromosome 1 (clone pUC1.77; Cooke and Hindley 1979); chromosome 7 (D7Z2, clone p7t1; Waye et al. 1987); chromosome 8 (D8Z2, clone pJM128; Donlon et al. 1986); chromosome 10 (D10Z1, clone p $\alpha 10 R P 8 ;$ Devilee et al. 1988); chromosome Y (DYZ3, clone pSP65; Cooke et al. 1982). The (peri)centromeric repetitive satellite DNA probes were labelled with biotin-14-dATP by nick translation of complete plasmid DNA according to the manufacturer's directions (BRL, Gaithersburg, Md., USA). DNA probes were stored at $-20^{\circ} \mathrm{C}$.

\section{In situ hybridization to tissue sections}

ISH was performed as described by van Dekken et al. (1992, 1993). Briefly, tissue sections were deparaffinized with xylene followed by $100 \%$ ethanol and then treated with $0.3 \% \mathrm{H}_{2} \mathrm{O}_{2}$ in methanol for 20 min to block endogenous peroxidase activity. To facilitate DNA probe accessibility to the cellular DNA, sections were digested with $0.4 \%$ pepsin (Sigma) in $0.2 \mathrm{M} \mathrm{HCl}$ at $37^{\circ} \mathrm{C}$ for $5-30$ min (mean $14 \mathrm{~min}$ ), after an incubation in $2 \times$ standard saline citrate $(\mathrm{SSC} ; \mathrm{pH} 7.0)$ at $70^{\circ} \mathrm{C}$ for $30 \mathrm{~min}$ to shorten the digestion time. Before applying the probe set, the optimal digestion time for each tumor was determined by a pepsin time series $(5,10,15,20$ $\min$ ).

Cellular DNA was heat denatured for $2 \mathrm{~min}$ in $70 \%$ formamide in $2 \times \mathrm{SSC}(\mathrm{pH} 7.0$ ), followed by dehydration in a graded ethanol series. Chromosome-specific repetitive DNA probes were denatured for $5 \mathrm{~min}$ at $70^{\circ} \mathrm{C}$ in a hybridization mixture containing $1-2$ $\mu \mathrm{g} / \mathrm{ml}$ probe DNA, $500 \mu \mathrm{g} / \mathrm{ml}$ sonicated herring sperm DNA (Sigma), $0.1 \%$ Tween-20,10\% dextran sulfate, and $60 \%$ formamide in $2 \times \mathrm{SSC}$ at $\mathrm{pH} 7.0$. Then, $30 \mu \mathrm{l}$ of probe mixture was applied to each slide. The slides were incubated overnight at $37^{\circ} \mathrm{C}$ in a moist chamber. Tissue sections were washed in $60 \%$ formamide in $2 \times$ $\mathrm{SSC}\left(\mathrm{pH} 7.0\right.$ ) at $42^{\circ} \mathrm{C}$ for $10-15 \mathrm{~min}$, then in $2 \times \mathrm{SSC}$ at $42^{\circ} \mathrm{C}$ for 10-15 min.

Histochemical detection was performed by immunoperoxidase staining. Slides were subsequently incubated for $30 \mathrm{~min}$ at $37^{\circ} \mathrm{C}$ with mouse anti-biotin (Dakopatts, Glostrup, Denmark), biotin-labelled horse anti-mouse (Vector, Burlingame, Calif., USA) and avidin-biotin complex (Vectastain Elite $\mathrm{ABC}$ kit). The probe-related signal was developed with diamihobenzidine $(\mathrm{DAB} ; 0.5 \mathrm{~g} / \mathrm{l}$ in $0.1 M$ PBS+imidazole with $0.05 \% \mathrm{H}_{2} \mathrm{O}_{2}$ ). The signal was amplified with $\mathrm{CuSO}_{4}(0.5 \%$ in $0.9 \% \mathrm{NaCl})$. Finally, the sections were counterstained with hematoxylin for $20 \mathrm{~s}$, rinsed in tap water, dehydrated in graded ethanol and xylene solutions and mounted in Malinol (Chroma-Gesellschaft, Köngen, Germany).

\section{In situ hybridization to nuclear suspensions}

Nuclear suspensions (concentration ranging from 0.5 to $5 \times 10^{6} \mathrm{nu}-$ clei/ml) in aliquots of $15 \mu \mathrm{l}$ were spotted on aminoalkylsilanecoated glass slides and air dried for at least $30 \mathrm{~min}$. The pretreatment had to be optimized for accurate ISH. The following procedure yielded the best results: Slides were heated in $2 \times \mathrm{SSC}(\mathrm{pH}$ 7.0 ) in a microwave oven at $85^{\circ} \mathrm{C}$ for $10 \mathrm{~min}$ at $600 \mathrm{~W}$, and rinsed in $2 \times \mathrm{SSC}$ at $37^{\circ} \mathrm{C}$. Then the nuclei were digested in $0.1 \%$ pepsin (Sigma) in $0.2 \mathrm{M} \mathrm{HCl}$ at $37^{\circ} \mathrm{C}$ for $5-7 \mathrm{~min}$ and rinsed again in PBS and $2 \times$ SSC, respectively. Denaturation, hybridization and detection were performed as described above.

\section{Evaluation of ISH results}

The DNA probe set was analyzed for the normal prostate and for each prostatic adenocarcinoma on consecutive 4- $\mu \mathrm{m}$ sections in a previously defined tissue area. For each of the probes, 100 ,intact“ (spherical) and non-overlapping $4-\mu \mathrm{m}$ nuclear slices were counted 


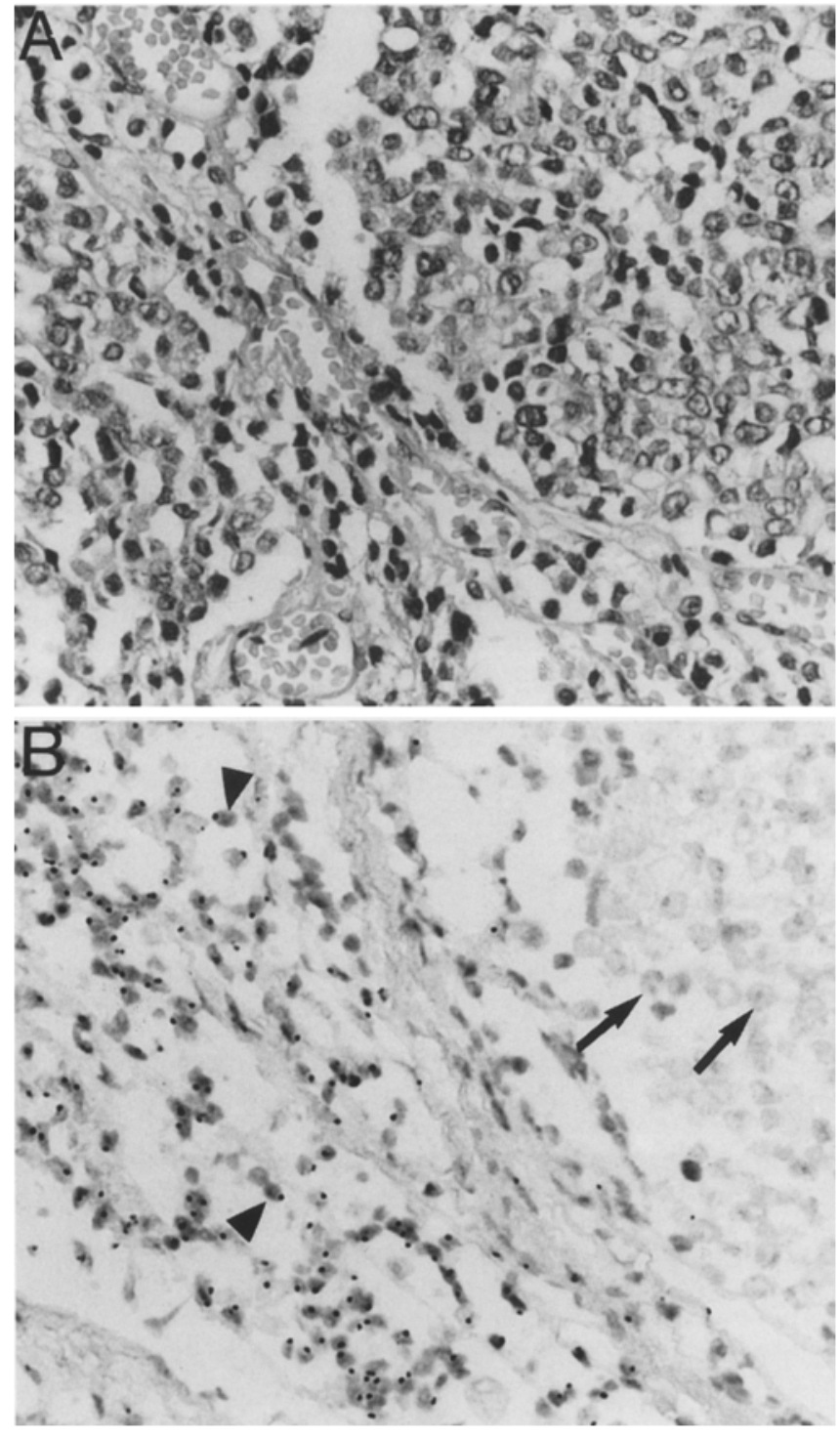

Fig. 2A Hematoxylin and eosin-stained tissue section of a Gleason 5 area of case 7, showing poorly differentiated tumor cells. B Same case: ISH with the $\mathrm{Y}$ probe to this tissue section. The $\mathrm{Y}$ chromosome is lost in one part of the tumor (arrows), whereas neighboring cancer cell nuclei still retain this chromosome (arrowheads). This illustrates the focal cytogenetic heterogeneity in prostatic tumors. This chromosome Y aberration could not be distinguished by suspension ISH. Magnification: A, B 361x

by two independent investigators (100 each) and the number of solid DAB spots per nuclear fragment was scored $(0,1,2,3,4,>4$ spots per nuclear slice). For the nuclear suspensions, 200 intact and non-overlapping nuclei were scored by each investigator. $\mathrm{Ag}$ gregates of nuclei were excluded from counting. The individual DNA probe spot distributions were then compared, and totalled when no significant counting differences between the investigators were found. Chromosome 1 was used as a measure for aneuploidy, since no numerical aberrations were found for this probe (Alers et al. 1995a). Further, in each case, non-aberrant probes revealed identical ploidy patterns.

The efficiency of hybridization was checked by careful inspection of ISH signals in stromal cells adjacent to tumor glands present in one section. Further, the quality of ISH was controlled in adjacent sections, hybridized with other DNA probes. Performing these controls, we never observed areas within one section with loss of ISH signal in both tumor and neighboring stromal cells for all probes. These artifacts might be seen when the tissue has different accessibility for the probe in different areas (e.g., due to variable fixation).

\section{DNA flow cytometry}

Nuclear DNA content in the deparaffinized tissues was measured as described by Hedley et al. (1983). Gleason-graded tumor areas were selectively cut out of the paraffin blocks and subsequently used for FCM and suspension ISH. Correspondence between upper and lower boundaries was seen in all tumor samples. FCM and analysis of the nuclei stained with ethidium bromide (Sigma) from these areas were performed using a Facscan (Becton Dickinson, Mountain View, Calif., USA). Tissue from a normal prostate served as a diploid control. A DNA index between 0.8 and 1.2 was considered diploid. The percentage of non-2C peak cells was derived from the flow histograms and used to determine the proportion of aneuploid/tetraploid cells of the graded area(s) within one tumor.

\section{Statistical analysis}

The probe spot distributions of both tissue sections and nuclear suspensions were evaluated statistically by means of the Kolmogorov-Smirnov (K-S) test (Young 1977). This statistical test is very suitable for two-sided comparisons of histograms or other distributions. The Pearson correlation coefficient was used to measure the degree of association of aneuploidy in the tissue sections and in the nuclear suspensions, as well as aneuploidy detected by ISH with the percentage of non-2C peak cells as measured by FCM. This correlation coefficient, $r$, measures the degree of ,straight line" association between the values of the two variables (Altman 1991).

\section{Results}

In situ hybridization to tissue sections and nuclear suspensions

The effect of nuclear slicing on cells in 4- $\mu$ m-thick sections of normal prostatic tissue, when compared with whole nuclei, is illustrated in Fig. 1. In tissue sections, approximately half of the truncated nuclei show no or one spot, which is as expected in view of the section thickness (Fig. 1A, C). More than $90 \%$ of the whole nuclei revealed the expected disomic signal for chromosome 1 (Fig. 1B, D). In the nuclear suspension $7 \%$ of the cells showed more than two spots, against $0 \%$ on the tissue sections (Fig. 1C, D). This is probably due to the focal presence of aneuploid cells or artifacts. It was also seen when fluorescent visualization of ISH signals was used (data not shown).

\section{Detection of chromosomal aberrations}

Numerical chromosomal aberrations for chromosomes 7 , 8 , and $\mathrm{Y}$ were seen in both tissue sections and nuclear suspensions (Table 1). Loss of chromosome 10 was seen in the tissue section of case 6 only. Histologically focal losses (Fig. 2) of chromosomes 10 and $\mathrm{Y}$ in cases 3, 4, and 7 could not be distinguished in the nuclear suspen- 

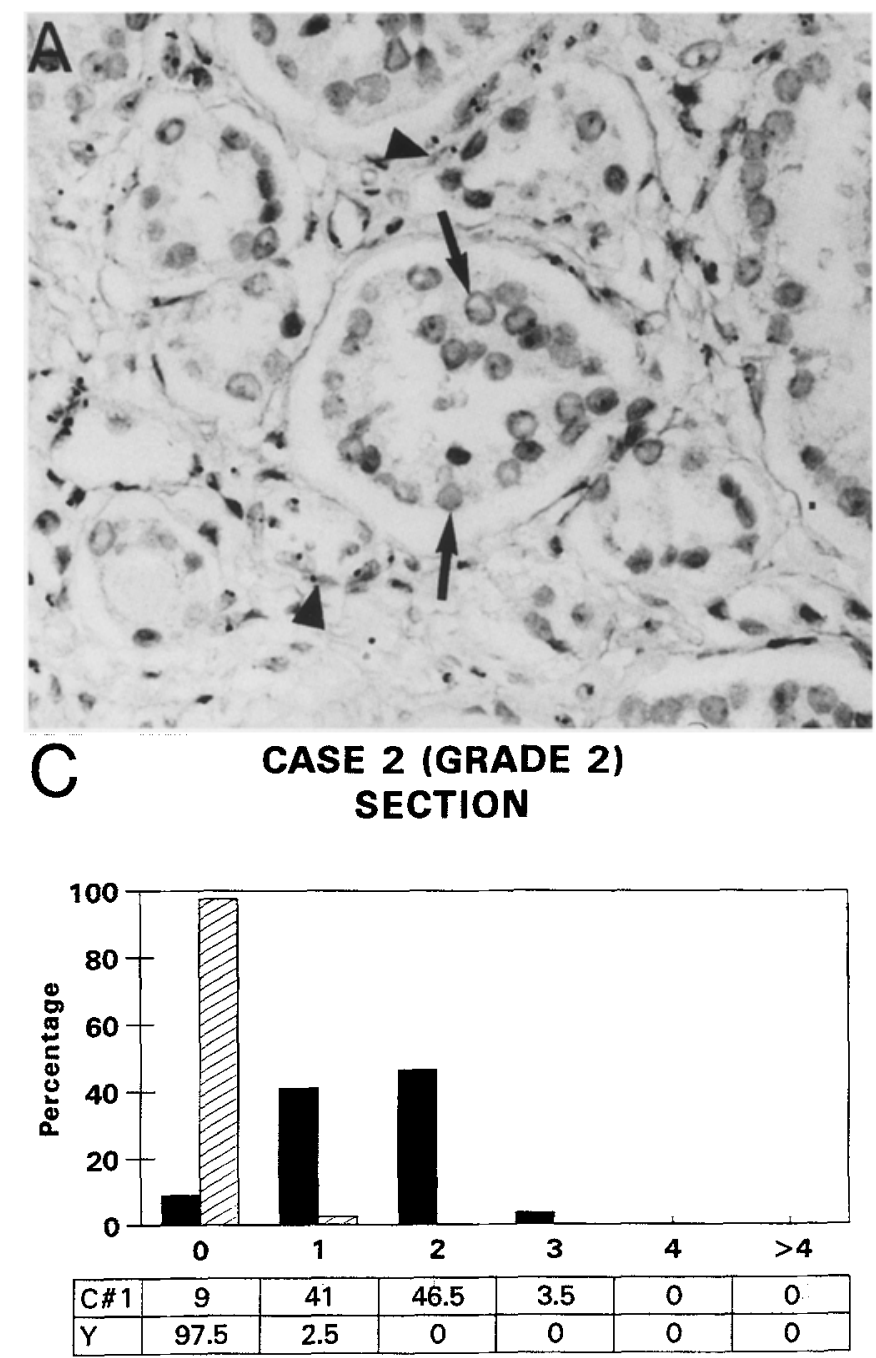

Number of ISH spots/ Nucleus

DE\#1 $\boxminus \mathrm{Y}$

Fig. 3A ISH to a well-differentiated area of case 2 (Gleason grade 2 ). Loss of the Y chromosome is seen in the tumor glands ( $a r-$ rows), but not in stromal tissue cells (arrowheads). B The corresponding nuclear suspension showing loss of $\mathrm{Y}$ in approximately half of the nuclei (arrows). The presence of Y-containing cells is seen, possibly of fibroblastic origin (arrowhead). Magnification: A $361 \times$, B 880x. C Bar histogram showing a near-total $Y$ loss in the tissue section. Chromosome 1 displays a few aneuploid nuclei. D Disaggregated cells showing about half of the nuclei with loss of the Y chromosome. Admixtures of stromal cells or tumor cells that still contain the $\mathrm{Y}$ chromosome might cause this discrepancy. In comparison with $\mathbf{C}$ the number of (chromosome 1) tetraploid nuclei is slightly higher

sions. Generally, chromosomal aberrations that occurred in large areas of the tissue section were seen in both sectiôn and corresponding suspension. In case 2, loss of the $\mathrm{Y}$ chromosome (nullisomy) was detected in almost all tumor cells in the tissue section and in about half of the disaggregated cells (Fig. 3). In case 6, a strong overrepresentation of chromosome 7 was seen by section ISH (Fig. 4A, C). This DNA tetraploid tumor (Table 1)
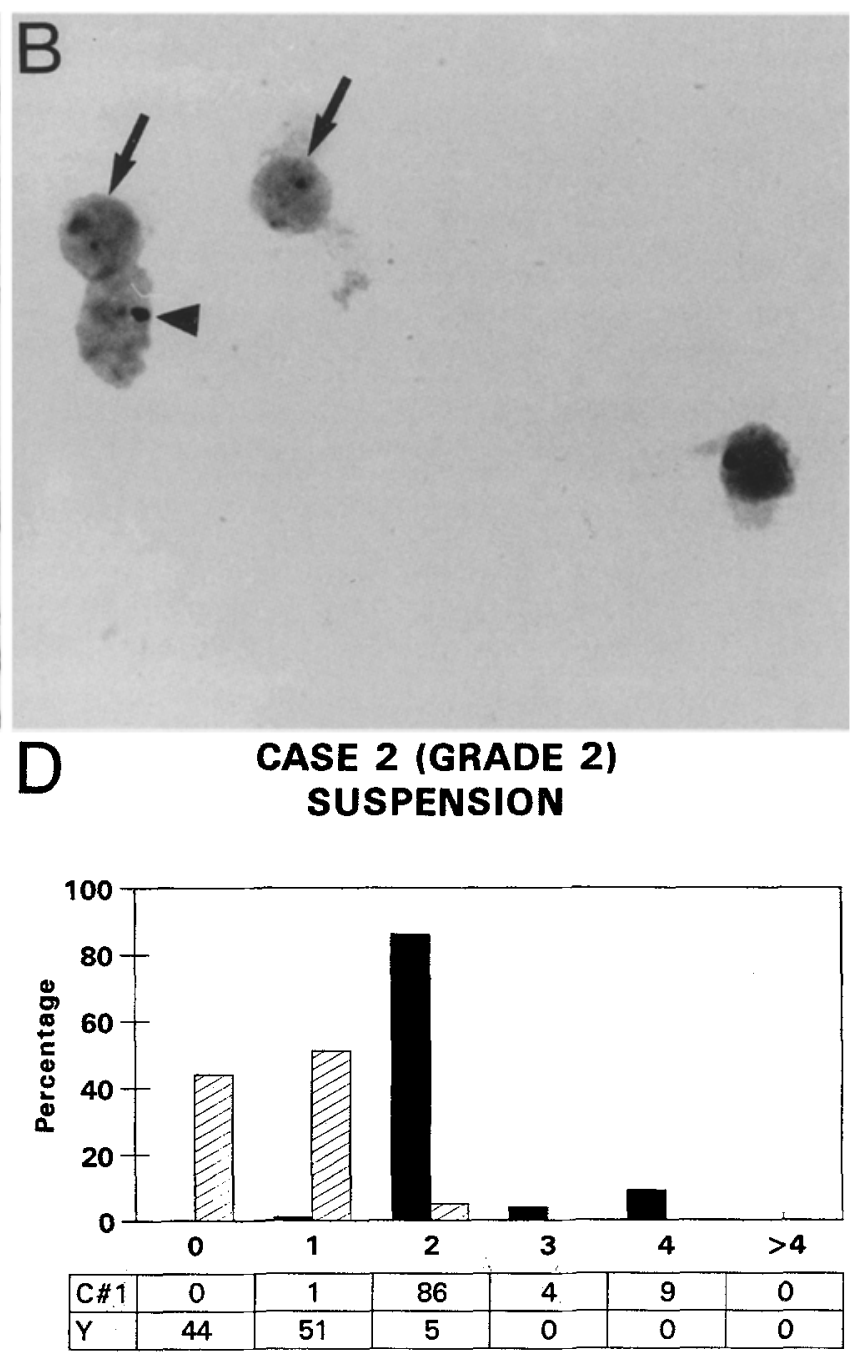

Number of ISH spots/ Nucleus

c\#1 19

showed a clear hexasomy for chromosome 7 in whole cell nuclei, suggesting trisomy 7 before polyploidization (Fig. 4B, D). In case 7, underrepresentation of chromosome 8 was seen as a monosomy in both tissue section and suspension ISH (Fig. 5). In case 4, a trisomy 7 was detected together with a high percentage of aneuploid cells in the nuclear suspension, but not in the tissue section (Table 1). ISH to sections at this lower level $( \pm 150$ $\mu \mathrm{m})$ in the tissue block also revealed overrepresentation of chromosome 7 and a higher rate of aneuploidy than in the original (upper) section, illustrating cytogenetic heterogeneity in this tumor. The same phenomenon accounts for the discrepancy in rate of aneuploidy in case 7 (Table 1).

Detection of aneuploidy

The percentages of aneuploid nuclei observed in tissue sections and suspensions corresponded with each other (Pearson correlation $r=0.8755, P<0.01$ ). Aneuploidy as 

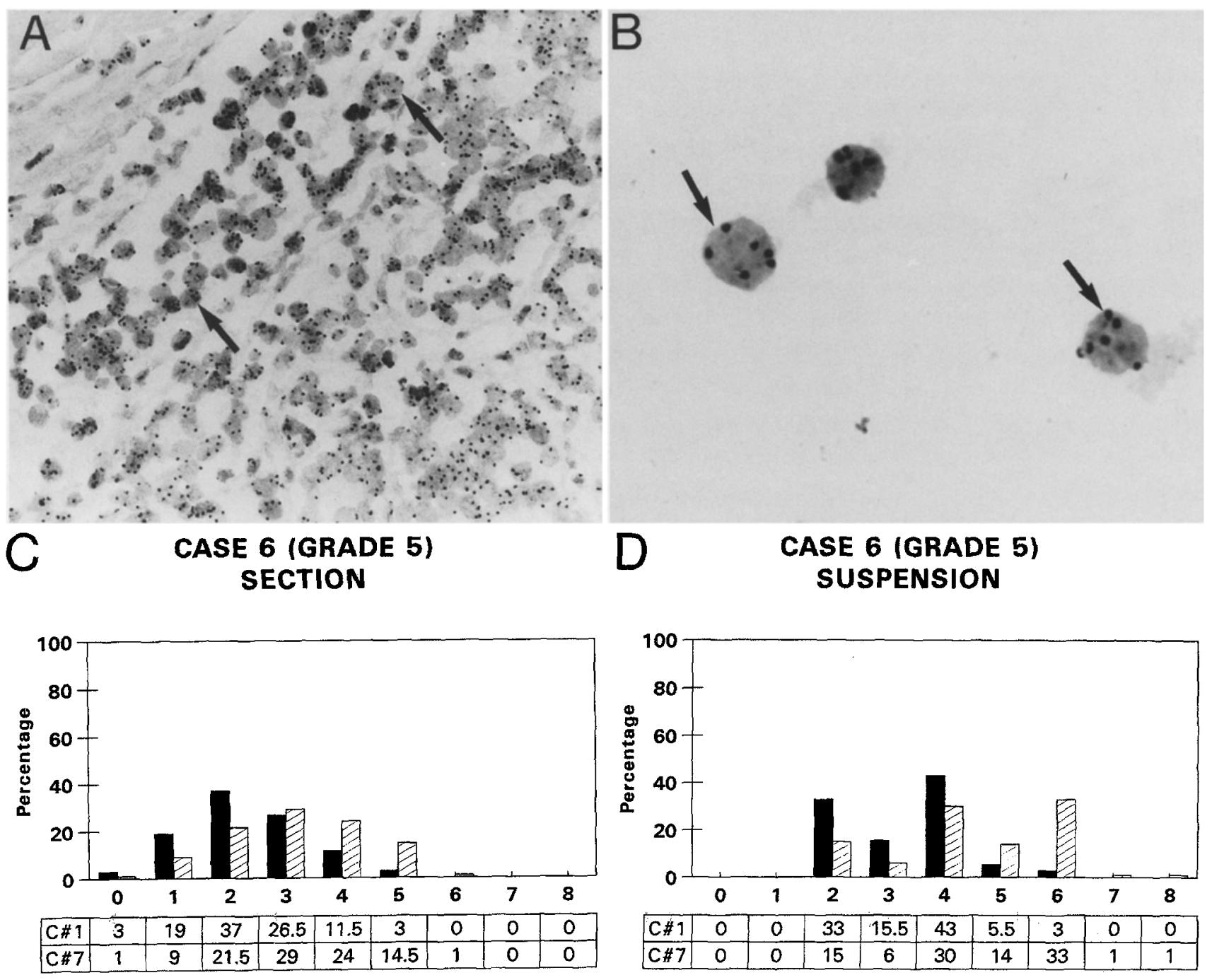

Number of ISH spots/ Nucleus

\section{DC\#1 $1 \mathrm{C \#} 7$}

Fig. 4A ISH to a tissue section of the poorly differentiated case 6 . In this tumor region (Gleason grade 5) many nuclei display more is than two spots for chromosome 7, a few are arrowed. B The corresponding nuclear suspension. Two nuclei hexasomic for chromosome 7 are seen (arrows). Magnification: A 361×, B 880x. C Bar histogram showing overrepresentation of chromosome 7 in the tissue section of case 6 , seen as a shift to the right of the spot distribution in comparison with chromosome 1 . In this section about $40 \%$ of the nuclei are aneuploid for chromosome 1 . D Nuclear suspension showing distinct peaks at two, four and six spots per nucleus for chromosome 7. Distinct peaks at only two and four spots per nucleus are seen for chromosome 1

assessed by ISH to sections and suspensions was in concordance with the proportion of non-2C peak cells, as measured by DNA FCM $(r=0.9301, P<0.001$, and $r=0.9393, P<0.001$, respectively). In general, the percentage of aneuploid nuclei was higher in the nuclear suspensions, especially in high-grade tumors (Table 1). In tissue sections, aneuploidy was seen by the presence of hyperdiploid cells. However, we could not distinguish between

\section{Discussion}

In this series of prostatic tumors, chromosomal aberrations $(+7,+8,-8,-10,-\mathrm{Y})$ were seen in both suspensions and tissue sections. Moreover, ISH to sections revealed focal aberrations $(-10,-Y)$ in four cases that could not be distinguished in the suspensions, probably due to dilution with non-aberrant cells. Therefore, only numerical aberrations that occurred in larger parts of the tumors were detected by the suspension method. In particular, gains of chromosomes were identified more 


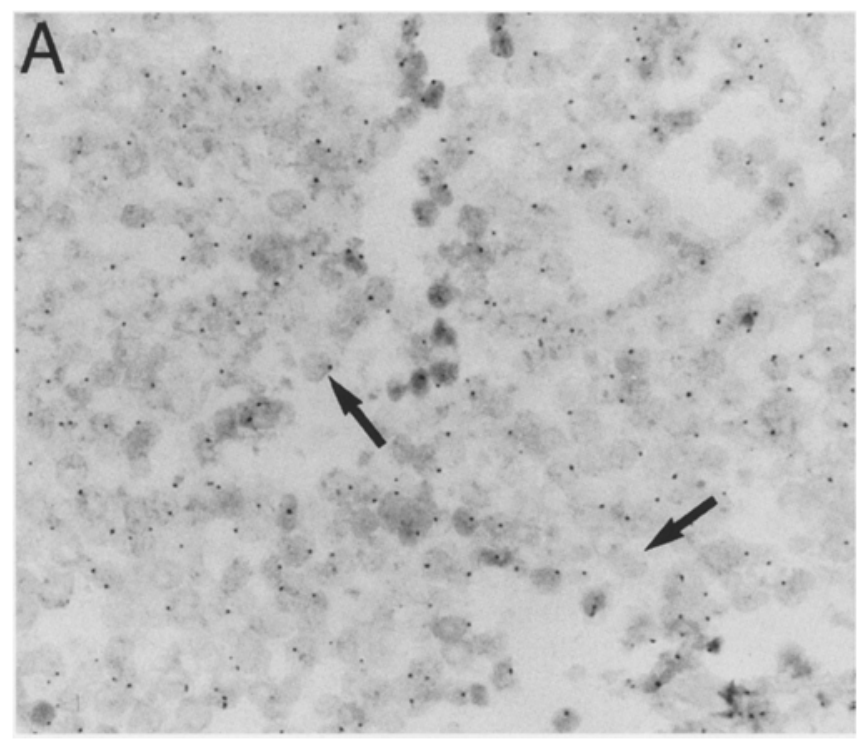

C

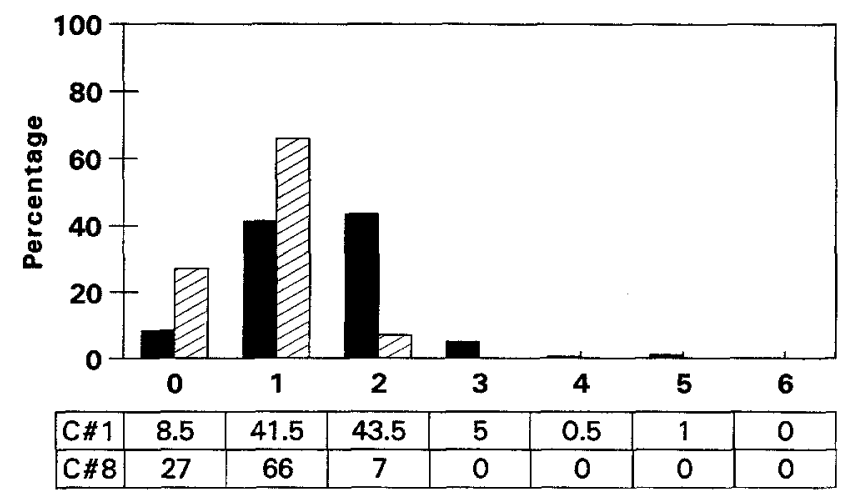

Number of ISH spots/ Nucleus

\section{口}

Fig. 5A ISH with the chromosome 8-specific probe to the tissue section of case 7 (Gleason grade 5). Many cells with no or only one spot per nucleus are seen, some are arrowed. B Corresponding nuclear suspension showing monosomy 8 in two tumor cells (arrows), whereas another cell (arrowhead) reveals disomy for this chromosome. Magnification: A 361x, B 880x. Bar histogram showing underrepresentation (monosomy) of chromosome 8 in the tissue section, illustrated by a peak at one spot per nucleus. D Nuclear suspension also revealing monosomy for chromosome 8 . A distinct peak at four spots per nucleus for chromosome 1 can be observed, revealing the tetraploid fraction

clearly by suspension ISH (case 6 , Fig. 4). In three tumors, ISH to disaggregated specimens confirmed nullisomy and monosomy for several chromosomes, already noted as chromosomal loss by section ISH (Table 1). The latter findings contradict the statement that, due to truncation effects, monosomy in a significant proportion of cells will be easily missed (Dhingra et al. 1994).

In general, the number of aneuploid cells detected by section and suspension ISH were in agreement with each
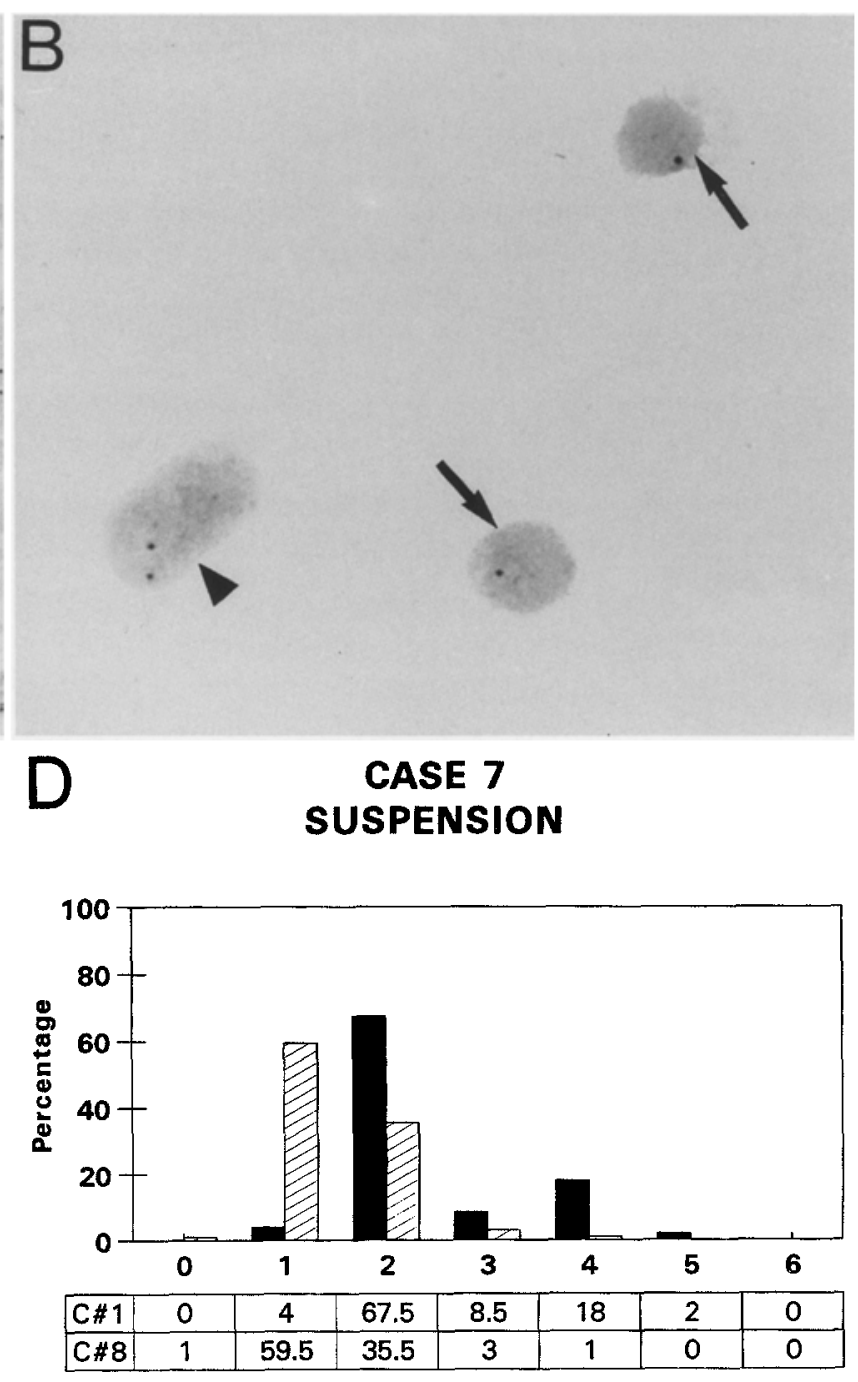

Number of ISH spots/ Nucleus

\section{c\#1 $\triangle \mathrm{C} \# 8$}

other $(P<0.01)$, and with DNA flow cytometry data (both $P<0.001)$. Therefore, in tissue sections, a good estimation of ploidy can be made, despite the truncation phenomenon. In our series the percentage of aneuploid cells was higher in the nuclear suspensions, especially in advanced tumors. In advanced prostate cancers the number of stromal cells is often lower than in well-differentiated cancers. This might lead to a relative increase in the percentage of aneuploid cells (Table 1). Further, heterogeneity in cellular DNA content in some specimens may account for the observed differences (cases 4 and 7).

Prostate adenocarcinomas are cytogenetically heterogeneous (Henke et al. 1994; Alers et al. 1995b). This is illustrated by case 4 . Upper and lower boundaries of the tissue showed the same morphology, whereas the cytogenetic status appeared different. As shown above, loss of information concerning focal cytogenetic alterations is one of the major drawbacks of working with disaggregated specimens of prostatic tumors. Another issue is to distinguish tumor cells from non-tumor cells. Immunolabel- 
ling with a tumor-specific marker could solve this problem. Also sorting of (labelled) tumor cells by flow cytometric methods with subsequent ISH can be applied (e.g., Beck et al. 1992). The major advantage of ISH to nuclear suspensions is that it allows direct visual assessment of the numerical chromosomal status, unbiased by truncation effects. Furthermore, it is a quick and easy to perform procedure. At present it is best suited for computeraided analysis of ISH (W.E. Mesker et al., in preparation).

Acknowledgements The authors wish to thank The Dutch Cancer Society for financial support (EUR 92-35) and Dr. W.C.J. Hop for statistical evaluation.

\section{References}

Alers JC, Krijtenburg PJ, Vissers CJ, Bosman FT, Kwast TH van der, Dekken H van (1995) Interphase cytogenetics of prostatic adenocarcinoma and precursor lesions: analysis of 25 radical prostatectomies and 17 adjacent intraepithelial neoplasias (PIN). Genes Chromosom Cancer 12:241-250

Alers JC, Krijtenburg PJ, Vissers CJ, Bosman FT, Kwast TH van der, Dekken $H$ van (1995b) Cytogenetic heterogeneity and histologic tumor growth patterns in prostatic cancer. Cytometry 20: (in press)

Altman DG (1991) Practical statistics for medical research. Chapman and Hall, London

Anastasi J, Le Beau MM, Vardiman JW, Westbrook CA (1990) Detection of numerical chromosomal abnormalities in neoplastic hematopoietic cells by in situ hybridization with a chromosome-specific probe. Am J Pathol 136:131-139

Arps S, Rodewald A, Schmalenberger B, Carl P, Bressel M, Kastendieck $H$ (1993) Cytogenetic survey of 32 cancers of the prostate. Cancer Genet Cytogenet 66:93-99

Beck JLM, Hopman AHN, Vooijs GP, Ramaekers FCS (1992) Chromosome detection by in situ hybridization in cancer cell populations which were flow cytometrically sorted after immunolabeling. Cytometry 13:346-355

Brothman AR, Peehl DM, Patel AM, McNeal JE (1990) Frequency and pattern of karyotypic abnormalities in human prostate cancer. Cancer Res 50:3795-3803

Cooke HJ, Hindley J (1979) Cloning of human satellite III DNA: different components are on different chromosomes. Nucleic Acids Res 6:3177-3179

Cooke HJ, Schmidtke J, Gosden JR (1982) Characterization of a human $\mathrm{Y}$ chromosome repeated sequence and related sequences in higher primates. Chromosoma 87:491-502

Cremer T, Tesin D, Hopman AHN, Manuelidis L (1988) Rapid interphase and metaphase assessment of specific chromosomal changes in neuroectodermal tumor cells by in situ hybridization with chemically modified DNA probes. Exp Cell Res 176:199-220

Dekken H van, Pizzolo JG, Reuter VE, Melamed MR (1990) Cytogenetic analysis of human solid tumors by in situ hybridization with a set of 12 chromosome-specific DNA probes. Cytogenet Cell Genet 54:103-107

Dekken H van, Kerstens HMJ, Tersteeg TA, Verhofstad AAJ, Vooijs GP (1992) Histological preservation after in situ hybridization to archival solid tumor sections allows discrimination of cells bearing numerical chromosome changes. J Pathol $168: 317-324$

Dekken H van, Bosman FT, Teijgeman R, Vissers CJ, Tersteeg TA, Kerstens HMJ, Vooijs GP, Verhofstad AAJ (1993) Identification of numerical chromosome aberrations in archival tumours by in situ hybridization to routine paraffin sections: evaluation of 23 phaeochromocytomas. J Pathol 171:161-171

Devilee P, Kievits T, Waye JS, Pearson PL, Willard HF (1988) Chromosome-specific $\alpha$ satellite DNA: isolation and mapping of a polymorphic alphoid repeat from human chromosome 10 . Genomics 3:1-7

Dhingra K, Sneige N, Pandita TK, Johnston DA, Lee JS, Emami K, Hortobagyi GN, Hittelman WN (1994) Quantitative analysis of chromosome in situ hybridization signal in paraffin-embedded tissue sections. Cytometry 16:100-112

Donlon T, Wyman AR, Mulholland J, Barker D, Bruns G, Latt S, Botstein D (1986) $\alpha$ Satellite-like sequences at the centromere of chromosome \#8. Am J Hum Genet 39:A196

Gleason DF (1992) Histologic grading of prostate cancer: a perspective. Hum Pathol 23:273-279

Hedley DW, Friedlander ML, Taylor IW, Rugg CA, Musgrove EA (1983) Method for analysis of cellular DNA content of paraffin-embedded pathological material using flow cytometry. J Histochem Cytochem 31:1333-1335

Heiden T, Wang N, Tribukait B (1991) An improved Hedley method for preparation of paraffin-embedded tissues for flow cytometric analysis of ploidy and S-phase. Cytometry 12:614-621

Henke R-P, Krüger E, Ayhan N, Hübner D, Hammerer P (1994) Frequency and distribution of numerical chromosomal aberrations in prostatic cancer. Hum Pathol 25:476-484

Hopman AHN, Poddighe PJ, Smeets AW, Moesker O, Beck JL, Vooijs GP, Ramaekers FC (1989) Detections of numerical chromosome aberrations in bladder cancer by in situ hybridization. Am J Pathol 135:1105-1117

Hopman AHN, Hooren E van, Kaa CA van de, Vooijs PGP, Ramaekers FCS (1991) Detection of numerical chromosome aberrations using in situ hybridization in paraffin sections of routinely processed bladder cancers. Mod Pathol 4:503-513

Kim SY, Lee JS, Ro JY, Gay ML, Hong WK, Hittelman WN (1993) Interphase cytogenetics in paraffin sections of lung tumours by non-isotopic in situ hybridization. Am J Pathol 142:307-317

Krishnadath KK, Tilanus HW, Alers JC, Mulder AH, Dekken H van (1994) Detection of genetic changes in Barrett's adenocarcinoma and Barrett's esophagus by DNA in situ hybridization and immunohistochemistry. Cytometry 15:176-184

Lundgren R, Mandahl N, Heim S, Limon J, Henrikson H, Mitelman F (1992) Cytogenetic analysis of 57 primary prostatic adenocarcinomas. Genes Chromosom Cancer 4:16-24

Micale MA, Sanford IS, Powell IJ, Sakr WA, Wolman SR (1993) Defining the extent and nature of cytogenetic events in prostatic adenocarcinoma: paraffin FISH vs. metaphase analysis. Cancer Genet Cytogenet 69:7-12

Persons DL, Hartmann LC, Herath JF, Borell TJ, Cliby WA, Keeney GL, Jenkins RB (1993) Interphase molecular cytogenetic analysis of epithelial ovarian carcinomas. Am J Pathol 142:733-741

Persons DL, Takai K, Gibney DJ, Lieber MM, Jenkins RB (1994) Comparison of fluorescence in situ hybridization with flow cytometric and static image analysis in ploidy analysis of paraffin-embedded prostate adenocarcinoma. Hum Pathol 25:678-683

Poddighe PJ, Moesker O, Smeets D, Awwad BH, Ramaekers FCS (1991) Interphase cytogenetics of hematological cancer: comparison of classical karyotyping and in situ hybridization using a panel of eleven chromosome specific DNA probes. Cancer Res 51:1959-1967

Wang N, Pan Y, Heiden T, Tribukait (1993) Improved method for release of cell nuclei from paraffin-embedded cell material of squamous cell carcinomas. Cytometry 14:931-935

Waye JS, England SB, Willard HF (1987) Genomic organization of alpha satellite DNA on human chromosome 7: evidence for two distinct alphoid domains on a single chromosome. Mol Cell Biol 7:349-356

Young IT (1977) Proof without prejudice: use of the KolmogorovSmirnov test for the analysis of histograms from flow systems and other sources. J Histochem Cytochem 25:935-944

Zitzelsberger H, Szücs S, Wier H-U, Lehmann L, Braselmann H, Enders S, Schilling A, Breul J, Höfler H, Bauchinger M (1994) Numerical abnormalities of chromosome 7 in human prostate cancer detected by fluorescence in situ hybridization (FISH) on paraffin-embedded tissue sections with centromerespecific DNA probes. J Pathol 172:325-335 